\title{
Dynamic Linkages between Health and Wealth in the European Union
}

\author{
George Konteos ${ }^{1}$, Constantinos Katrakilidis ${ }^{2 *}$, Kyriaki Sotiriadou ${ }^{2}$ \\ ${ }^{1}$ Department of Business Administration, Western Macedonia University of Applied Sciences, Myrsini, Greece \\ ${ }^{2}$ Department of Economics, Aristotle University of Thessaloniki, Thessaloniki, Greece \\ Email: gkonteos@teiwm.gr, *katrak@econ.auth.gr, ksoritiadou@yahoo.gr
}

How to cite this paper: Konteos G., Katrakilidis, C. and Sotiriadou K. (2018) Dynamic Linkages between Health and Wealth in the European Union. Theoretical Economics Letters, 8, 709-719. https://doi.org/10.4236/tel.2018.84048

Received: January 17, 2018

Accepted: March 5, 2018

Published: March 8, 2018

Copyright (c) 2018 by authors and Scientific Research Publishing Inc. This work is licensed under the Creative Commons Attribution International License (CC BY 4.0).

http://creativecommons.org/licenses/by/4.0/

\section{(c) () Open Access}

\begin{abstract}
The relationship of health and wealth has been for long the subject of academic research as well as a hot policy issue. In this paper we examine this relationship using data on infant mortality rate and real GDP per capita for the 28 European Union countries over the period 1960-2012. The long-run and short run dynamics of the relationship are examined through panel co-integration tests, error correction models and Granger causality tests. The empirical analysis reveals the existence of a long-run negative relationship between GDP and infant mortality. In the short-run there are bidirectional causal effects between the two variables. In summary, the two variables affect each other in a spiral way.
\end{abstract}

\section{Keywords}

Infant Mortality Rate, Income, Panel Data Analysis

\section{Introduction}

Europe has experienced impressive economic development after World War II, together with improvements in health that led to very high life expectancy and very low mortality levels for the citizens of the continent. Average real GDP per capita increased by $140 \%$ in the 28 countries of the EU from 1960 to 2012. During the same period, life expectancy (at birth, in years) increased by $15 \%$, from 69.02 in 1960 to 79.10 in 2012 and infant mortality (infant deaths per 1000 live births) decreased hugely by $89 \%$, from 39.94 in 1960 to 4.20 in 2012 .

In this paper we try to investigate the dynamic relationship of health and wealth among the EU countries, using GDP per capita and infant mortality rates. The panel data set for the $28 \mathrm{EU}$ countries expands over the period 1960-2012. The data set is unbalanced, since for some countries (mostly the former eastern 
Bloc countries) data for GDP are available from 1990 and on. The source of the data set is the World Development Indicators, issued by the World Bank.

In the next section we discuss the relevant literature and in section 3 we present in more detail the data we used in the study. We follow in section 4 with some methodological issues and the results of the empirical analysis. Our final section concludes the study and provides some policy recommendations.

\section{Literature Review}

The linkages between health and wealth have been studied extensively in the literature, as it has been a matter of interest in many areas of economics, such as development economics, health economics, macroeconomics, etc. The health status of the populations of poor countries is undoubtedly lower than that of the rich countries, as it is evident in all datasets collected by international organizations. As Hamoudi and Sachs [1] state "poverty and ill health occur together", so the opposite is also true.

Many researchers tried to examine the mechanism behind the connection between health and wealth. The main question refers to the direction of causality, i.e. is health improved through income growth or a healthier population can produce more thus increasing income? Moreover, a bidirectional causality, with a feedback between health and income, might also be present.

There are arguments supporting all three cases. Traditional development theory suggests that the relationship usually runs from income to health [2] [3] [4]. As a country becomes more developed the level of health services provided to the population becomes higher and therefore the health status of the population increases. In other words, higher income provides access to goods and services which improve and enhance health (improved nutrition, access to clean water, better education, and improvements in health systems).

On the other hand, improved health status of a population might lead to higher income levels. Using a large amount of biometric data Fogel [5] suggested that increases in calories intake for the working class of England from the late $18^{\text {th }}$ century and on explains about $30 \%$ of per capita GDP increase in the last two centuries. Many other studies suggest that causality runs from health to income [6] [7] [8] [9] [10]. Above all, Nordhaus [11] stresses the fact that improvements in health status in the U.S. have yielded phenomenal increases in economic well-being. He emphatically states: "It is sobering to reflect that, were the author of this paper to have experienced the 1900 life table, the odds are long that this paper would have been written from beyond the grave."

The mechanism behind the income increases through health improvements might refer to: i) Improvements in productivity (healthier workers are more productive because they are stronger physically and mentally), ii) Education (healthier people having a higher life expectancy invest more in their skills' improvement which leads to increased productivity and, in turn, to higher income, iii) Investment in physical capital (higher life expectancy leads people to increase 
their savings, which leads to increased investment and thus higher income. There is also increased foreign direct investment to countries with a healthy and highly educated workforce, leading to increased income.

The connection between health and wealth is not only a research question investigated by academics, but an issue of major importance in the political agenda as well. Deaton [12] points out that "policy cannot be intelligently conducted without an understanding of mechanisms; correlations are not enough. Income might cause health, health might cause income, or both might be correlated with other factors", establishing the direction of causality may lead to the adoption of specific policies. If the wealth to health causality is accepted then policies should aim at increasing income. Otherwise, if the health to wealth causality is accepted then policies aiming or at bettering the health status of people should be implemented.

However, there is an increased body of literature that advocates for a bidirectional causal relationship, in which health and income are focal points in a spiral dynamic relationship [12] [13].

\section{Data on Health and Wealth}

In the vast majority of studies wealth, or income, is measured by GDP per capita, usually in logarithmic form, in order to estimate percentage changes rather than unit changes. Accordingly, in this paper we use the natural logarithm of real GDP per capita on 2005 PPP US\$ for the 28 EU countries over the period 1960-2012. For some countries, mainly those of the former Eastern Europe, data on GDP are available after the dissolution of the Eastern Bloc, i.e. after 1990. Therefore, the data set we use is unbalanced. The source of the data set is the World Development Indicators, issued by the World Bank.

As for health, the two most commonly indicators used in the literature to represent the health status of a population are life expectancy at birth measured in years and infant mortality, measured by the number of infant deaths per 1000 live births. In our study we use infant mortality as we consider it the most important indicator which represents the health status of a population during a period of time. Again, the source of the data set is the World Development Indicators, issued by the World Bank. Life expectancy, albeit being a very important indicator commonly used in many studies, is derived through various calculations, whereas infant mortality measures deaths directly and thus is a more tangible and solid quantity. Of course many studies follow different approaches, for example examining the connection between GDP and health expenditure (among others, [14] [15]).

All the above measures have certain deficiencies and shortages, which are noted in the literature. For example, GDP per capita is an average which ignores distribution of income across individuals or across geographic regions within a country. Also, life expectancy and infant mortality do not really represent the quality of life or the quality of health status of a population. 
However, the above indicators have also advantages which make them very popular among researchers. Most important is the fact that these indicators are readily available for most countries of the world and the methodology used in their calculation is communal, thus making comparisons across time and countries possible. In other words, GDP per capita and infant mortality comprise a consistent data set, which is particularly suitable for causality analysis of the kind we attempt in this paper.

GDP per capita and infant mortality have been used in two recent studies [16] [17], which also explore the health and wealth nexus. However, in the Chen et al. study the question is examined for a panel of developing countries using quinquennial data, whereas in the Ergoğan et al. study, which is for the panel of the OECD countries, no causality analysis is used. Hence, our study, by using causality analysis for the EU countries with annual data over the long period of 1960-2012, contributes in the relevant literature by shedding light over the particular issue of health and wealth in Europe.

In the study the following countries are included: Austria, Belgium, Bulgaria, Croatia, Cyprus, Czech Republic, Denmark, Estonia, Finland, France, German, Greece, Hungary, Ireland, Italy, Latvia, Lithuania, Luxemburg, Malta, the Netherlands, Poland, Portugal, Romania, Slovakia, Slovenia, Spain, Sweden and the United Kingdom. This group of 28 countries comprise the European Union today (the last country that joined is Croatia, in 1/7/2013), and they represent the largest part of the European continent. There are huge differences among these countries in almost all variables one could examine, and of course the differences are larger in the past years and they appear to lessen in recent years After all, the whole process of European unification is directly aiming at removing differences in the socioeconomic level of development, and promote cohesion and integration into a single economic area for the member countries.

In Table 1 summary statistics for real GDP per capita and infant mortality rate are given for the whole period as well as for the first and last year of the period.

In Figure 1 the average of the variables is depicted over the period 1960 to 2012, which is the year with the latest available data at the time of the study. It is clear that there is an increase in real GDP per capita (GDP) and a decrease in infant mortality (IMR) thus forming an X-shape which is typical for many countries. For example, we see that the depiction for Greece (Figure 2) is quite similar to that of the averages of the 28 countries.

Table 1. Summary statistics for real GDP per capita and infant mortality rate, EU-28, 1960-2012.

\begin{tabular}{ccccccccc}
\hline & Mean & Mean & St. dev. & St. dev. & Min 1960 & Min 2012 & Max 1960 \\
& 1960 & 2012 & 1960 & 2012 & & & \\
\hline GDP & $10,717.81$ & $26,014.29$ & 3832.67 & 7915.38 & Hungary 2037.07 & Bulgaria 4633.83 & Luxemburg 21,355.05 & Luxemburg 77,971.3 \\
IMR & 36.9 & 4.2 & 17.7 & 2.2 & Sweden 16.4 & Luxemburg 1.7 & Portugal 84.4 & Romania 10.7 \\
\hline
\end{tabular}

Source: World Development Indicators, World Bank. 


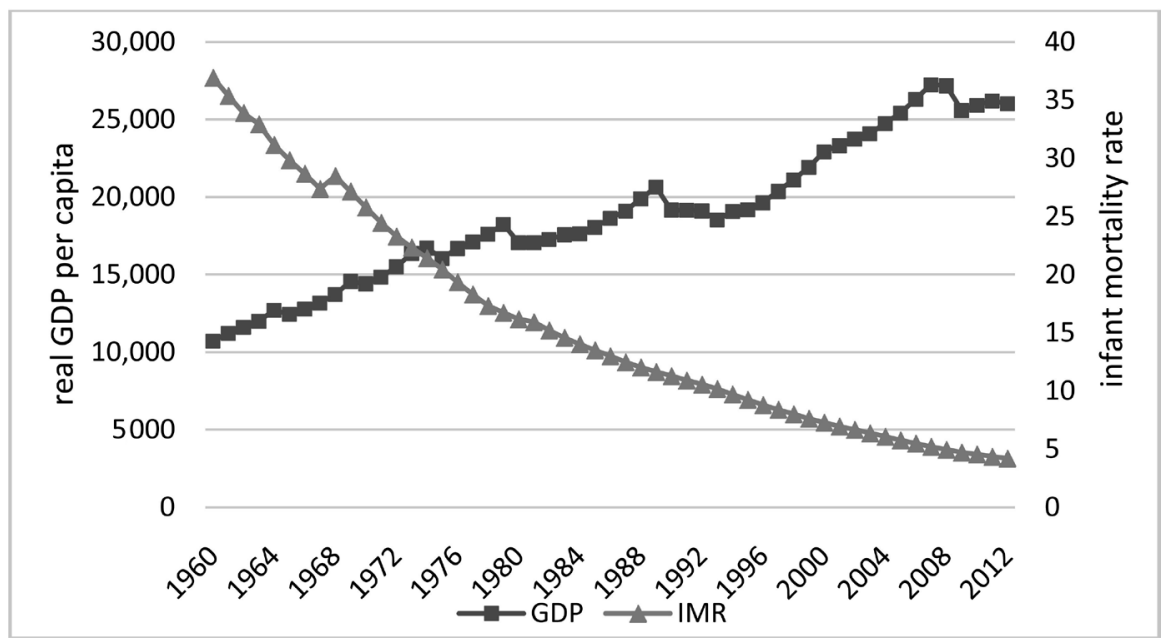

Figure 1. Real GDP per capita (GDP) and infant mortality rate (IMR), EU average, 1960-2012.

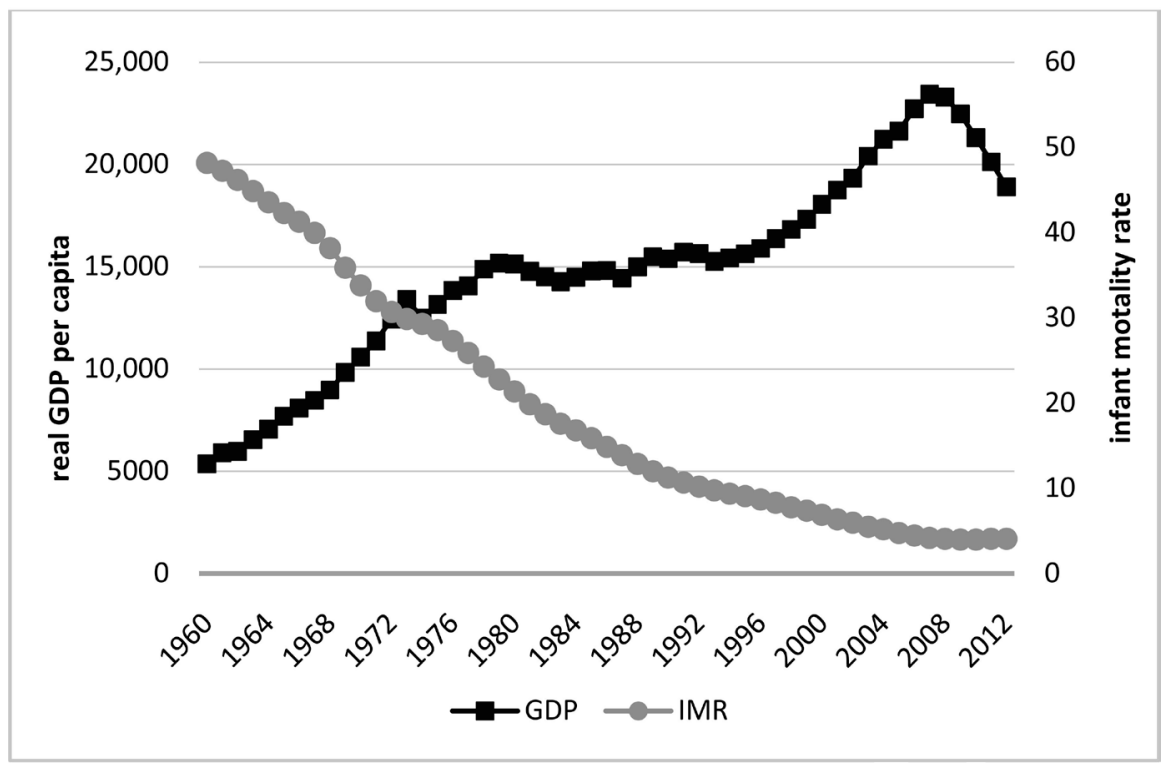

Figure 2. Real GDP per capita (GDP) and infant mortality rate (IMR), Greece, 1960-2012.

However, there are some countries which exhibit an interesting picture. For example, in Figure 3 data for Bulgaria are depicted for the period 1980-2012.

It is clear that we have a crisscrossing figure which indicates that the two variables, real GDP per capita and infant mortality rate respond to each other in a negative manner. In the first few years of the examined period infant mortality rate was falling and real GDP per capita was increasing. When GDP started to decline in 1988 we had some years where infant mortality rate increased, and then, again, wan GDP started to increase infant mortality rate declined.

\section{Methodological Issues and Empirical Analysis Results}

In order to investigate the relationship of real GDP per capita (GDP) and infant 


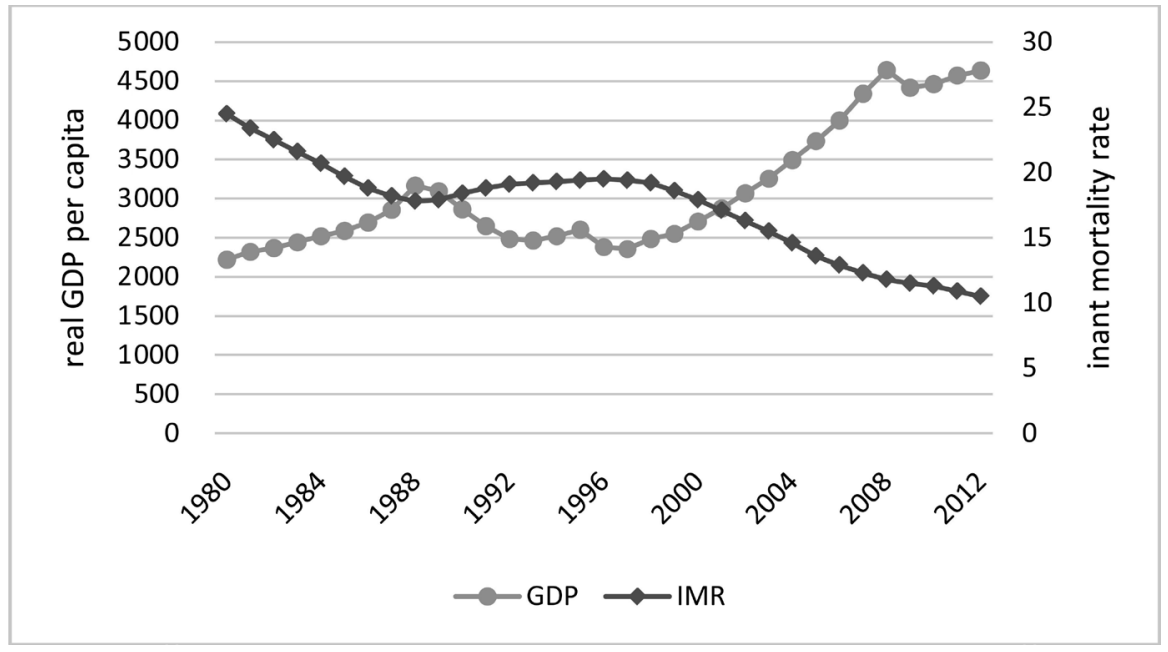

Figure 3. Real GDP per capita (GDP) and infant mortality rate (IMR), Bulgaria, 1980-2012.

mortality rate (IMR) we estimate the following regression:

$$
I M R_{i, t}=a_{i}+b_{i} G D P_{i, t}+e_{i, t}
$$

Note that IMR is expressed in percentage terms. As a first step in our empirical analysis we will perform unit root test in order to examine the variables for stationarity. Provided that the variables will be found non-stationary in levels we can then examine the existence of a co-integration relationship between them, i.e. the presence of a long-run equilibrium relationship. The next step is to estimate an error correction model in order to examine the adjustment process towards equilibrium. We also estimate the model using the Fully Modified Ordinary Least Squares (FMOLS) and Dynamic Ordinary Least Squares (DOLS) methods, which provide information on the long-run elasticities of the variables and improve the robustness of our results. Finally, we use Granger causality tests so as to look at the direction of causality between the variables.

Three panel unit root test were performed (Table 2), namely the Breitung t-stat test [18], the Im, Pesaran and Shin test [19], and the ADF-Fisher chi-square test [20].

The panel unit root tests indicate that both variables are non-stationary in levels and they become stationary in first differences. In other words, both series are I(1) procedures and therefore we can search for a co-integrating relationship between them. That in turn means that we can have a linear combination of the variables which is $\mathrm{I}(0)$ and it displays a long-run equilibrium relationship.

The presence of a co-integrating relationship between the variables can be confirmed with the Johansen [21] and the Kao [22] tests (Table 3 and Table 4 respectively).

Both tests have the null hypothesis of no co-integration, which is rejected. Moreover, from the Johansen-Fisher test we conclude at the 5\% level that there is at most 1 co-integration relationship. In Table 5 we present the estimates of this relationship, which is in essence the long-run equilibrium relationship $I M R_{i, t}=a_{i}+b_{i} G D P_{i, t}+e_{i, t}$. 
Table 2. Panel unit root tests.

\begin{tabular}{ccccc}
\hline \multirow{2}{*}{ Test } & \multicolumn{2}{c}{ GDP } & \multicolumn{2}{c}{ IMR } \\
\cline { 2 - 5 } & Levels & $1^{\text {st }}$ difference & Levels & $1^{\text {st }}$ difference \\
\hline \multirow{2}{*}{ Breitung } & 7.92602 & $-10.1522^{* * *}$ & 8.44755 & $-6.27302^{* * *}$ \\
& $(1.0000)$ & $(0.0000)$ & $(1.0000)$ & $(0.0000)$ \\
Im, Pesaran and Shin & 0.87115 & $-15.6485^{* * *}$ & 0.36060 & $-5.30874^{* * *}$ \\
& $(0.8082)$ & $(0.0000)$ & $(0.6408)$ & $(0.0000)$ \\
ADF-Fisher & 50.6210 & $339.677^{* * *}$ & 66.9435 & $156.780^{* * *}$ \\
& $(0.6779)$ & $(0.0000)$ & $(0.1502)$ & $(0.0000)$ \\
\hline
\end{tabular}

Note: probability values in parentheses, null: unit root (assumes common unit root process) for the Breitung t-stat test and unit root (assumes individual unit root process) for the other two, ${ }^{* *}$ denotes rejection of the null at the $1 \%$ level.

Table 3. Johansen Fisher panel co-integration test.

\begin{tabular}{ccccc}
\hline Hypothesized & Fisher stat. & \multicolumn{3}{c}{ Fisher stat. } \\
\hline No. of CE $(\mathrm{s})$ & (from trace test) & Prob. & (from max-eigen test) & Prob. \\
\hline None & $221.2^{* * *}$ & 0.0000 & $206.6^{* * *}$ & 0.0000 \\
At most 1 & $71.70^{*}$ & 0.0770 & $71.70^{*}$ & 0.0770 \\
\hline
\end{tabular}

Note: ${ }^{*}$ denotes significance at the $10 \%$ level, ${ }^{* *}$ denotes significance at the $5 \%$ level, ${ }^{* *}$ denotes significance at the $1 \%$ level.

Table 4. Kao residual co-integration test.

\begin{tabular}{ccc}
\hline & t-statistic & Prob. \\
\hline ADF & $-3.891412^{* * *}$ & 0.0000 \\
\hline
\end{tabular}

Note: ${ }^{*}$ denotes significance at the $10 \%$ level, ${ }^{* *}$ denotes significance at the $5 \%$ level, ${ }^{* *}$ denotes significance at the $1 \%$ level.

Table 5. Long-run equilibrium relationship.

$$
\begin{gathered}
\mathrm{IMR}=3.44519-0.221349^{* *} \mathrm{GDP} \\
(2.57041)
\end{gathered}
$$

Note: $t$ values in parentheses, ${ }^{* *}$ denotes significance at the $5 \%$ level, ${ }^{* * *}$ denotes significance at the $1 \%$ level.

The coefficient of GDP in the long-run equilibrium relationship reveals that a $1 \%$ change in GDP will lead to an opposite direction change in IMR by around 0.22 .

At the next stage of our empirical analysis we employ two more estimation procedures, the Fully Modified Ordinary Least Squares (FMOLS) and the Dynamic Ordinary Least Squares (DOLS), in order to confirm the robustness of our analysis. The results of the two procedures are given in Table 6 .

With both methods the coefficient of the respective explanatory variable is negative confirming the opposite relationship of GDP and IMR. In the long-run, as IMR changes by $1 \%$ there is a negative change in GDP by about $0.2 \%$ and as GDP changes by $1 \%$ there is a negative change in IMR by about $1.25 \%$ to $1.48 \%$. These results seem quite reasonable and within the expected magnitude. 
Table 6. The long-run coefficients with the FMOLS and DOLS methods.

\begin{tabular}{ccc}
\hline Dependent variable & FMOLS & DOLS \\
\hline \multirow{2}{*}{ GDP } & $-0.203934^{* * *}$ & $-0.190567^{* * *}$ \\
& {$[0.005851]$} & {$[0.010566]$} \\
& $(0.0000)$ & $(0.0000)$ \\
IMR & $-1.488665^{* * *}$ & $-1.242614^{* * *}$ \\
& {$[0.010638]$} & {$[0.065742]$} \\
& $(0.0000)$ & $(0.0000)$ \\
\hline
\end{tabular}

Note: standard error in brackets, probability values in parentheses, ${ }^{* * *}$ denotes significance at the $1 \%$ level.

Table 7. Granger causality tests.

\begin{tabular}{|c|c|c|}
\hline Causality direction & Chi-sq. & Prob. \\
\hline ectIMR & \multicolumn{2}{|c|}{$\begin{array}{c}-0.010397^{* * *} \\
(-11.2472)\end{array}$} \\
\hline ectGDP & \multicolumn{2}{|c|}{$\begin{array}{l}-0.000363 \\
(-0.23582)\end{array}$} \\
\hline $\mathrm{GDP} \rightarrow \mathrm{IMR}$ & $4.918104^{\star *}$ & 0.0266 \\
\hline $\mathrm{IMR} \rightarrow \mathrm{GDP}$ & $19.39663^{\star * *}$ & 0.0000 \\
\hline
\end{tabular}

Note: ${ }^{* *}$ denotes significance at the $5 \%$ level, ${ }^{\star * *}$ denotes significance at the $1 \%$ level.

Since we have a long-run relationship between the two variables, which are co-integrated, we can estimate an error correction model of the form of Equations ((2) and (3)) below, which confirms the existence of a co-integration relationship between the two variables. The error correction model connects the long-run equilibrium relationship with the short-run adjustment mechanism, in other words, it displays how the two variables react when they deviate from the long-run equilibrium and how fast they adjust to it [23].

$$
\begin{gathered}
\Delta G D P_{i}=a_{1 i}+\sum_{j=1}^{p} B_{j} \Delta G D P_{i, t-j}+\sum_{j=1}^{p} \Gamma_{j} \Delta \mathrm{IMP}_{i, t-j}+c_{1} e c_{i, t-1}+\varepsilon_{i, t}^{1} \\
\Delta I M R_{i}=a_{2 i}+\sum_{j=1}^{p} B_{j} \Delta G D P_{i, t-j}+\sum_{j=1}^{p} \Gamma_{j} \Delta \mathrm{IMP}_{i, t-j}+c_{2} e c_{i, t-1}+\varepsilon_{i, t}^{2}
\end{gathered}
$$

We present the estimates of the error correction model in Table 7. The error correction term for Equation (2) is statistically not significant. The error correction term for Equation (3) is negative and statistically significant, which means that there is an adjustment towards the long run equilibrium by around $1.1 \%$. Therefore, the error correction model displays also the direction of the causality in the long-run, in our case runs from GDP to IMR.

We next proceed with Granger causality tests [24] in order to examine the direction of causality for the relationship in the short-run (Table 7).

According to the Granger causality tests there are bidirectional short-run effects between the two variables. Changes in income affect infant mortality and this is quite reasonable and expectable. An increasing GDP will bring about better health conditions for the population and this is reflected in lower infant 
mortality rates. The opposite happens with decreasing GDP: the health status of the population deteriorates. However, there are also causal effects running the other way around: from infant mortality to GDP. Perhaps this happens because infant mortality is a very important health indicator and as it changes there will be some response to society's income. For example, if infant mortality increases then the health system will require more resources to cope with this increase and this will affect GDP.

\section{Summary and Concluding Remarks}

The relationship of health and wealth has been for long the subject of academic research as well as a hot policy issue. According to common practice in the literature, infant mortality rate and real GDP per capita have been used in the present study to study the health and wealth nexus in the 28 European Union countries over the period 1960-2012. The long-run and short run dynamics of the relationship have been examined through panel co-integration tests, error correction models and Granger causality tests.

The empirical analysis revealed the existence of a long-run negative relationship between GDP and infant mortality. In the short-run there are bidirectional causal effects between the two variables. In summary, the two variables affect each other in a spiral way.

Income is an important factor affecting health through better nutrition, better living conditions and better health services provision. On the other hand, improved health of the population (as this is reflected in reduced infant mortality) affects positively GDP, possibly through improvements in productivity and population longevity in general. Therefore, investments in health lead to increased income and development levels and increasing income leads to better health status of the population. As former WHO Director-General Dr. Gro Harlem Brundtland stated on the occasion of the launch of the Report of the Commission on Macroeconomics and Health "a healthy population is a prerequisite for growth as much as a result of it" [25].

\section{References}

[1] Hamoudi Amar, A. and Sachs, J.D. (1999. Economic Consequences of Health Status: A Review of the Evidence. Working Paper No 30, Center for International Development (CID) at Harvard University, Harvard, MA.

[2] Bloom, D. and Canning, D. (2000) The Health and Wealth of Nations. Science, 287, 1207-1209. https://doi.org/10.1126/science.287.5456.1207

[3] Zhang, J., Zhang, J. and Lee, R. (2003) Rising Longevity, Education, Savings and Growth. Journal of Development Economics, 70, 83-101. https://doi.org/10.1016/S0304-3878(02)00088-3

[4] Bloom, D., Caning, D. and Jamison, D. (2004) Health, Wealth and Welfare. Finance and Development, 31, 10-15.

[5] Fogel, R.W. (1993) Economic Growth, Population Theory, and Physiology: The Bearing of Long-Term Processes on the Making of Economic Policy. Nobel Prize 
Lecture. http://nobelprize.org/nobel_prizes/economics/laureates/1993/

[6] Bhargava, A., Jamison, D.T., Lau, L.J. and Murray, C.J.L. (2001) Modeling the Effects of Health on Economic Growth. Journal of Health Economics, 20, 423-440. https://doi.org/10.1016/S0167-6296(01)00073-X

[7] Bloom, D. and Canning, D. (2000) The Health and Wealth of Nations. Science, 287, 1207-1209. https://doi.org/10.1126/science.287.5456.1207

[8] Aguayo-Rico, A., Guerra-Turrubiates, I. and Montes de Oca-Hernández, R. (2005) Empirical Evidence of the Impact of Health on Economic Growth. Issues in Political Economy, 14, 45-58.

[9] Doeksen, G.A. (2006) The Changing Face of Economic Development: Health Care as an Economic Engine. EcoMod International Conference on Regional and Urban Modeling, Brussels, June 1-3 2006, 1-27.

[10] van Ourti, T., van Doorslaer, E. and Koolman, X. (2009) The Effect of Income Growth and Inequality on Health Inequality: Theory and Empirical Evidence from the European Panel. Journal of Health Economics, 28, 525-539. https://doi.org/10.1016/j.jhealeco.2008.12.005

[11] Nordhaus, W.D. (2002) The Health of Nations: The Contribution of Improved Health to Living Standards. Cowles Foundation Discussion Paper No. 1355. Yale University, New Haven, CT.

[12] Deaton, A. (2002) Policy Implications of the Gradient of Health and Wealth. Health Affairs, 21, 13-30. https://doi.org/10.1377/hlthaff.21.2.13

[13] French. D. (2012) Causation between Health and Income: A Need to Panic. Empirical Economics, 42, 583-601.

[14] Dreger, C. and Hans-Eggert, R. (2005) Health Care Expenditures in OECD Countries: A Panel Unit Root and Cointegration Analysis. International Journal of Applied Econometrics and Quantitative Studies, 2, 5-20.

[15] De Mello-Sampayo, F. and de Sousa-Vale, S. (2014) Financing Health Care Expenditure in the OECD Countries: Evidence from a Heterogeneous, Cross-Sectional Dependent Panel. Panoeconomicus, 61, 207-225. https://doi.org/10.2298/PAN1402207M

[16] Chen, W., Clarke, J.A. and Roy, N. (2013) Health and Wealth: Short Panel Granger Causality Tests for Developing Countries. Econometrics Working Paper EWP1204, Department of Economics, University of Victoria, Victoria.

[17] Erdoğan, E., Ener, M. and Arıca, F. (2013) The Strategic Role of Infant Mortality in the Process of Economic Growth: An Application for High Income OECD Countries. Procedia-Social and Behavioral Sciences, 99, 19-25. https://doi.org/10.1016/j.sbspro.2013.10.467

[18] Breitung, J. (1999) The Local Power of Some Unit Root Tests for Panel Data. Discussion Papers, Interdisciplinary Research Project 373: Quantification and Simulation of Economic Processes, No. 1999, 69, Humboldt University Berlin.

[19] Im, K.S., Pesaran, H.M. and Shin, Y. (2003) Testing for Unit Roots in Heterogeneous Panels. Journal of Econometrics, 115, 53-74. https://doi.org/10.1016/S0304-4076(03)00092-7

[20] Maddala, G.S. and Wu, S. (1999) A Comparative Study of Unit Root Tests with Panel Data and a New Simple Test. Oxford Bulletin of Economics and Statistics, 61, 631-652. https://doi.org/10.1111/1468-0084.61.s1.13

[21] Johansen, S. (1988) Statistical Analysis of Cointegration Vectors. Journal of Economic and Control, 12, 231-254. https://doi.org/10.1016/0165-1889(88)90041-3 
[22] Kao, C. (1999) Spurious Regression and Residual-Based Tests for Cointegration in Panel Data. Journal of Econometrics, 90, 1-44. https://doi.org/10.1016/S0304-4076(98)00023-2

[23] Engle, R.F. and Granger, C.W.J. (1987) Cointegration and Error Correction: Representation, Estimation and Testing. Econometrica, 55, 251-276. https://doi.org/10.2307/1913236

[24] Granger, C.W.J. (1987) Causal Inference. The New Palgrave: Econometrics. W.W. Norton, New York.

[25] WHO (2001) Macroeconomics and Health: Investing in Health for Economic Development. Report of the Commission on Macroeconomics and Health, Geneva. 